\title{
Combating Islamic State in Iraq and Syria: Challenges and Recommendations
}

\author{
Masood Ur Rehman Khattak ${ }^{1}$ Ali Khan Ghumro ${ }^{2}$, and Amjad Ali Abro ${ }^{3}$
}

\begin{abstract}
Since the devastating incident of $9 / 11$, the terrorists have become more destructive and transnational in nature. This contemporary trend in terrorism has poured new seeds of unrest and turmoil around the globe. The emergence of Islamic States in Iraq and Syria is one of the same worries, having potential of massive destruction and fatalities across the region. Being wealthiest terrorist organization with huge stockpiles of weapons IS declared caliphate in 2014. This is alarming for the international community because IS has emerged as an organized, structured, well trained and highly motivated force in contemporary times. Though, there have been efforts launched to sweep this ferocious group by the US led alliance and regional stakeholders as well, these efforts remained either inadequate or counterproductive. The prevailing situation in the region concerned has also caused tensions in EU, South Asia and rest of the world. Keeping this backdrop in view, this study investigates the emergence, structure, funding sources and nature of terrorist activities of IS. Moreover, this research would be an attempt to highlight the challenges and opportunities for countering the menace of IS.
\end{abstract}

Keywords: Islamic State; NATO; GCC; Russia; Terrorism.

\section{Introduction}

The menace of terrorism might be as old as human being and it has kept on disturbing the peace of mind during every era. Over the year, the acts of terrorism have become more aggressive, volatile and destructive. The most common motivations in acts of terrorism might be categorized as ideological, political, economic and religious. Lately, it has been observed that terrorism in the name of religions is rising. Whether it is due to poor understanding of the religion or to malign the religions - the reasons haves to be identified anyhow. The world seems divided on the definition of terrorism too which also is a great challenge for the academicians and policy makers to device counter measures. One of the horrific developments on the subject is the emergence of IS in Syria and Iraq. It has not only enveloped the region into mayhem but also has potential to impact the whole world as IS has carried out terrorist attacks in Middle East, Europe etc. One may assume that this threat would not be easy to eliminate in near future. Moreover, the recent efforts and strategy to combat

${ }^{1}$ Department of Politics and International Relations International Islamic University Islamabad, Pakistan.

${ }^{2}$ Department of International Relations University of Sindh, Jamshoro, Sindh, Pakistan.

${ }^{3}$ Department of International Relations, University of Karachi, Sindh, Pakistan.

*)Corresponding Author.

Email: masood.rehman@iiu.edu.pk 
IS seems flawed at many steps. There are issues which require attention such as strong organizational structure of IS, weak Iraqi and Syrian security apparatus, lack of commitment from the US and NATO to deploy adequate ground troops, divergence of interests among key players including Russia, America, Iran and GCC states. So, with this context, this article would investigate three main areas. First part would cover brief introduction of Islamic State, its organizational structure, strength, capabilities and sources of funding. Second part would be focused on major challenges in combating the Islamic State. Last part would suggest some recommendations to counter IS with the hope of peace and stability at regional and global level.

\section{The Emergence of Islamic State}

The evolution of IS is linked to the US attack on Iraq in 2003. Iraq under Saddam Hussein was in relative peace and stability, since he had firm control over Iraq and the Iraqi security forces were capable enough to mitigate any insurgency. But after the attack by the US, the security agencies, army police and intelligence were withered away. Resultantly, militant groups like AlQaeda found space to infiltrate Iraq and carry out insurgency against the US led alliance and newly installed Iraqi government. Al-Qaeda also installed its branch with the name Al-Qaeda in Iraq- (AQI) in 2004 (Knight, 2015). This group led by Musab Al-Zarqawi (Died in 2006) started fighting against the US forces and Iraqi government. The intensity of insurgency was low after his death, because of the determined efforts by the US and Iraqi security forces. Later on, Abu Bakr Al-Baghdadi became the leader of Islamic State in Iraq (ISI) during 2010 (Brisard, 2014).

This group was closely aligned with Al-Qaeda and mainly composed of Sunni Iraqis and the loyalists of Saddam. After 2010, Al Baghdadi reformed and regrouped ISI capabilities and focused on the Sunni tribes of Iraq where predominantly Saddam had wide support (Brisard, 2014). Previously, the Sunni tribes were marginalized by US because of their support to Saddam and later predominantly Shia government. Therefore, people from Sunni areas joined ISI led insurgency and within few years, the ISI militants controlled vast areas in Iraq, declared Islamic state (Caliphate) and Al-Baghdadi became Caliph in 2014. IS and Al-Qaeda were working together in Iraq and Syria before the declaration of Caliphate, but now Al-Qaeda leader Ayman Al Zawahiri disassociated himself from the Islamic State (Burca, 2014). Since 2014, this terrorist group has killed thousands of people in Iraq and Syria creating mass exodus of the local population. A collective counter operation was launched under the leadership of America, NATO, Saudi Arabia, Iran, Jordon, Kuwait, Qatar and many other states. Resultantly, thousands of IS linked militants including some of the key leaders were killed but still they control vast areas in Iraq and Syria. The Islamic State want to control those areas which were once part of great Muslim empires under first four Caliphs, Umayyad, Abbasid period and the Ottoman Empire (Ahmad, 2014). IS controls almost 90,000 Sq. km. area in Iraq and Syria (LaHaye, 2015). 
Physical space allowed this group to recruit, establish training centers, and become a safe heaven or a breeding ground for the transnational militant groups to carry out terrorist activities around the globe.

They want to impose sanctions and taxes on the non-Muslims, extermination of rival sects and non-Muslims, prohibition on women education, execution without proper trial, and revival of slavery are just few examples of their atrocious rule. In last few years, the IS militants have carried out mass scale killing of Shias, Yazidi tribe, Christians, foreign aid workers, journalists and personnel of Iraqi military forces. It is assumed that the IS militants would wage global Jihad against Western countries and expand their ideology in other states. The rise of IS has jolted the world peace and compelled the regional and global powers to curb this menace.

\section{The Organization and Structure of the Islamic State}

According to Sun Tzu "Know yourself and know your enemy" if one wants victory. Keeping this strategy in view one should know the structure of this militant group, for the success of IS operations lies in its composed organization. Al Baghdadi and his key advisors comprise of his executive branch, called as Al-Imara, holds key position and final decisions. For Syria the IS has designated former military official Abu Ali Al-Anbari as deputy of Al Baghdadi (Thompson \& Shubert, 2015) and Abu Muslim Al-Turkmani, a former military personnel of the Iraqi forces as deputy to their Caliph for Iraq. The induction of Saddam's loyalists has strengthened the capabilities of IS. The orderly delegation of command makes it easier for Al Baghdadi to govern the territories in Syria and Iraq (Thompson \& Shubert, 2015).

The two designated deputies forward the command of their Caliph to the local governors for implementation at local level. The advice for media relations, publicity, propaganda, recruitment, security and financial matters comes from the top and implemented by these sub commanders. There is a Shura council which advises Al Baghdadi on religious matters, decrees related to non-Muslims, rival sects, executions and focus on the adherence of their own extremist ideology (Thompson \& Shubert, 2015). The Delegative command and control structure of IS makes it well organized unit; if any commander is dead, he is soon replaced which means this organization is hard to be exterminated and it would take long term comprehensive strategy to neutralize this menace.

\section{The Strength and Capabilities of the Islamic State}

The militants of IS are well equipped, organized, trained and highly motivated. The major weapons cache came to IS after it captured the second largest town of Iraq, Mosul; they also looted three major arms depots getting crucial military gear to sustain their insurgency against Iraqi and Syrian military forces (UNSC-Resolution 2170, 2014). The IS militants possess enough weapons to sustain their insurgency for two years. The IS militants possess 
anti-aircraft weapons which could target aircraft flying at 16,000 ft. as well as low flying helicopters and drones (Bender \& Rosen, 2014).

Besides, the IS has also acquired Main Battle Tanks- (MBTs), truck mounted anti-aircraft guns, armor vehicles, short range missiles, sniper rifles, artillery and expertise of improvised explosive devices- IEDs. The IED manufacturing factories are operational under the areas controlled by the IS in Iraq and Syria. Due to these capabilities IS becomes most powerful terrorist organization in the world. Hence, US led alliance is reluctant to send their ground troops to Iraq. Surprisingly, most of the weapons with IS militants are from the US, Russian and Chinese origin (Bender \& Rosen, 2014).

\section{Challenges in Combating Islamic State and Other Militants 5.1 Inadequate Ground Offensive by the US Led Alliance}

According to the UN Security Council Resolution 2170, "terrorism can only be defeated by a sustained and comprehensive approach involving the active participation and collaboration of all States........" (UNSC Resolution-2170, 2014). Perhaps, this was helpful that US has been successful in getting the support of around 60 countries against the IS (Jim, 2015). To overcome this threat a five prong strategy as mentioned below, has been devised to counter IS in Iraq and Syria (Allen, 2014).

1. Providing military support to partners

2. Impeding the flow of foreign fighters

3. Stopping ISIL's financing and funding

4. Addressing humanitarian crises in the region

5. Exposing ISIL's true nature

The Operation Inherent Resolve (OIR) was launched as part of collective efforts against IS in this region. Perhaps, this seems productive due to extraordinary air superiority of US led coalition. As a result of US air strikes, the operational capacity of the IS may be eliminated as it is diminishing at the moment. Moreover, air superiority would also play an important role while ground offensive against IS. So far the US and coalition forces are confined to air strikes, training of Iraqi troops and intelligence coordination. They might not lead the ground offensive and may plan to use Iraqi army, militias, Kurd and regional partners for this purpose.

As of May 10, 2016, the US led alliance has carried out 12,199 air strikes in Iraq and Syria (US DoD, 2016). More than 8,322 air strikes took place in Iraq whereas 3,877 strikes targeted militants in Syria. Out of 12, 199 military strikes the US alone carried out 9,309 strikes against the IS targets and other coalition partners were responsible for 2,890 strikes in Iraq and Syria. The US led coalition has spent $\$ 7.2$ billion on military operations against IS (US DoD, 2016). The US has also decided to send 200 strong Expeditionary Targeting Force (ETF) to Iraq to target IS sanctuaries, hunt militants and support the Iraqi forces. 
The US has also requested $50 \%$ increase in the budget to combat IS, which may touch $\$ 7.5$ billion, the budget request also include $\$ 45000$ GPS guided smart bombs, and laser guided rockets worth $\$ 1.8$ billion (McInnis, 2016). Despite spending huge amount, the IS organization is still intact and they are operating with greater impunity in Iraq and Syria. A lesson may be learned here that better technology and air strikes may not guarantee success on ground in cases like IS and Afghan Taliban.

The US led air strikes have killed more than 10,000 IS fighters till now (Naylor, 2015). However, killing foot soldiers or mid-level commanders is not the permanent solution of this problem. Because the IS control vast areas and population of over a million. The recruitment of IS never stops; killed commanders and fighters are quickly being replaced.

If we compare it with Pakistan's strategy, Pakistan deployed over 150,000 troops in its tribal belt (Bhatty, 2014) which is not more than $27000 \mathrm{Sq}$. Km (ADB, 2014) and achieved success against militants (Ashraf, 2016). Keeping in mind the size of IS and the area they control, it is necessary that there must be a coalition of about 300,000 troops for ground offensive in Iraq and Syria.

This coalition has contributed only 1,000 trainers and military advisors to enhance the operational competence of Iraqi and Kurdish forces to prevent IS expansion and to launch offensive to get back the lost areas (Dominique, 2015). Additionally, the US led alliance in Syria is largely focused on the removal of Bashar-Al-Asad instead of operations against IS, Al-Nusra front and other terrorist groups. The US-Russia discord over Syria is another source of concern in the fight against terrorism. Russia is of the opinion that BasharAl-Asad should stay in Syria because of its strategic alliance. The friction has benefited the IS presence in Syria. It is imperative for the international community to work collectively to overcome this unprecedented challenge to global security.

\subsection{Russian Strategic Interests in Syria}

Russia considers Syria as strategic ally for a number of reasons. First, Russia is operating a naval base in Syria at Tartu which provides Russia access to Mediterranean Sea and beyond. In addition, Russia does not want to lose an ally who buys considerable amount of Russian made weapon and equipment. Russia is also operating a Hmeymim air base in Latakia, from where most of the air strikes were launched against Syrian rebels, IS, Chechens and AlQaeda affiliated militants in Syria.

Although, Russia has announced withdrawal of some portion of its military but its air base in Latakia is still active and operational with Mi-28 helicopters and latest aircraft (Pleitgen, 2016). Russian aircraft are still carrying out attacks against rebels and other militant groups (RANE, 2016). It was also observed that Syria imported $48 \%$ of Russian arms from 2006 to 2010. Russian defense firms also announced that they would continue the supply of KAB-500 guided aircraft bombs to Syria. The KAB-500 is highly accurate and can carry warhead of about $195 \mathrm{~kg}$ at delivery speed of 1100 
$\mathrm{km} / \mathrm{h}$. (Jones, 2015). Such a highly advance weapon would change the whole game in Syria. It is highly effective against insurgent and militant groups in Syria.

Mi-24 helicopter has also played crucial role in the counter insurgency operations in Syria (Cenciotti, 2015). This helicopter is considered as a flying tank because of its size and ability to carry huge weaponry. It can carry fully loaded eight soldiers in a battlefield. MI-24 has got 2,190- horsepower Klimove TV3-117 turbine engines with cruising speed of about $208 \mathrm{miles} / \mathrm{h}$, a ceiling of 14, 750 and a maximum range of 456 miles, which makes it a nightmare for adversaries (Tucker, 2009). The Russian Mi-24 may face some challenges in Syria, because the IS militants and Syrian rebels already possess Man Portable Air Defense Systems which can take down low flying aircraft or helicopters. The US has also plans to equip the Free Syrian Army rebels with surface to air missile capabilities. The US wants to repeat same strategy which they applied in 1980s against Soviet Union in Afghanistan (Entous, 2016). Such an approach is dangerous and would further destabilize Syria and invite counter measures from Russia. Comparatively, the situation in Syria is different from Afghanistan, because Russia has got active ground support from Iran and Hezbollah to save Bashar-Al-Asad regime

The US led alliance and GCC states must come to a collective agreeable political compromise over Syria with Asad Regime, Russia and Iran. Minus Bashar-Al-Asad formula may not be acceptable for Russia and Iran. It would hurt global efforts against the IS and other Al-Qaeda affiliated terrorist groups in Syria.

Russia is also facing terrorism and extremism in its own Caucasus belt. Russian policy makers believe that Chechen fighters are also moving to Syria and Iraq to join the Islamic State. Such a collaboration between Chechen militants and IS fighters is one of the main concern in the minds of Russian decision makers. The Chechen fighters would benefit from their collaboration with IS and seriously challenge the national security of Russia (N, 2015). It is believed they are also going to target Chechens along with other militant groups fighting the Bashar Al-Asad regime. In this way Russia is going to protect its ally and also eliminate threats to its homeland by Chechen fighters. The Chechen militants are operating in and around Latakia and Aleppo near Turkish border where Russian aircraft was shot down by Turkey over air space violation. Having been hard hit by Russia, the Chechen militant leader Muslim Shishani addressed online and asked for help from other terrorist factions fighting in Syria. He also declared that due to Russian operations many Chechens were deserted and joined the IS (Vatchagaev, 2016).

After downing of its aircraft by Turkey, Russia has deployed S-400 missiles in Syria to protect its aircraft from Israeli or NATO air strikes. The S400 is the most advanced and sophisticated anti-aircraft weapon system in the Arab world and it is regarded as a game changer in the region. With the induction of this system, US, NATO and Israel would cautiously make their moves in Syria. They would not be able to operate freely in Syrian airspace 
(Yashar, 2015). This anti-aircraft missile can take down objects flying at 90,000 feet with a maximum range of 250 miles. This anti-aircraft weapon system can track up to 300 targets at the same time with six anti-aircraft missile launchers. These attributes make it the most lethal weapon system in the Arab world putting pressure on Israel and NATO at the same time.

The deployment of S-400 may prove as game changer in Syria because it would cover almost whole of Syrian air space, large part of Turkey, the eastern side of the Mediterranean Sea, and most of Israeli airspace (Yashar, 2015). The lethality of the weapon system increases with its range of $600 \mathrm{~km}$ and the potential to hit targets about $400 \mathrm{~km}$ away at a blazing speed of 17,000 $\mathrm{km} / \mathrm{h}$ (Simha, 2015). The S-400 deployed in Syria would make Syria a no-fly zone for US/NATO allies. The relationship between Russia and US led alliance would get worse and may lead to escalation. The global efforts against IS, Al-Nusra front and other Al-Qaeda affiliates would suffer a great deal in such a situation. So, it is important for all the stakeholders to negotiate transition in Syria in an affable environment and come up with acceptable truce over Syria.

\subsection{Regional Rivalries/ Proxy Wars}

The tug of war between Iran and Saudi Arabia has also affected the efforts against IS in Syria. Iran is ally of Bashar Al-Asad, it is supporting Asad regime to consolidate its writ over areas under the control of IS and Free Syrian Army. Whereas Syria is facing two pronged challenge; first from Syrian opposition parties, mainly the Free Syrian Army and other rebels. This group is backed by the US, NATO (Rajab, 2014) and GCC states (Silander, 2015). Second challenge comes from the IS, Al-Nusra Front and other affiliated terrorist groups (Hitchcock, 2016). This is the reason that Syrian President sought support of the other actors which include Iran, Russia and Hezbollah. Syria has become a center of gravity of regional rivalries and proxy wars. Moreover, refugee crisis would get worse and it would benefit IS and other terrorist groups. It is necessary that regional powers must focus their energies on common enemy, IS and al-Qaeda linked terrorist groups and resolve Syrian impasse in an amicable way.

\section{Recommendations for Peace \\ 6.1 Regional and Global Alliance}

Major economic and military powers, Muslim countries especially the neighboring states must take the lead with adequate troops, weapon and equipment to combat IS. The estimated strength of the IS discussed in this study, is around 31 thousand in Iraq and Syria; to root out such a huge, well trained and highly motivated force, the international coalition must allocate atleast a five times larger force.

The level of threat posed by the IS demands comprehensive strategy at regional and global level. Although under the leadership of America, 60 countries have teamed up to counter this threat, but that is not enough. Being 
militarily and economically strong, Russia and Iran must also be part of this alliance in the fight against IS. The US, Russia, Saudi Arabia and Iran must mend their ties to defeat IS in this region.

\subsection{Intelligence Sharing and Coordination}

The use of modern technology would be a game changer in the fight against highly motivated IS fighters. The global powers should pour efforts to enhance the capacity of Iraqi, Syrian and Kurdish intelligence capabilities as well. As a compelling force with an effective organizational structure, IS would require equal amount of counter efforts for elimination. This might be the reason that they were able to exploit the weak areas of Iraqi and Syrian security forces. To defeat such a force there is a need of enhanced intelligence sharing and coordination among all stake holders. The Iraqi security forces including Peshmerga (Kurd) forces are poorly equipped and would require an awesome support by the developed countries to combat IS.

\subsection{Counter Narrative to Islamic State's Ideology}

The role of religious scholars cannot be ignored in this regard. There have been many decrees by the religious scholars against IS ideology. Besides, there must be a counter narrative with logic and supportive arguments from Quran and Hadith. In September 2014 a group of 152 religious scholars wrote a letter to Al-Baghdadi outlining gross violations of Islamic values by the IS in Iraq and Syria. They clearly said it is forbidden in Islam to force people to convert, deny women their rights, kill the innocent; re-introduction of slavery; torture people; declare a caliphate without consensus from all Muslims; and Jihad in Islam is a defensive war. Their argument and criticism were logical and validated by empirical references from Quran and Hadith. Such a narrative is required to dispel wrong interpretation of Islamic values by the IS militants. The true picture of Islam should be revived for peace and harmony with the help of learned Ulmas and respective Muslim countries.

\subsection{Reconstruction and Development/Poverty Alleviation}

IS, Al-Qaeda, Boko Haram, Al-Shebab and TTP target impoverished societies for their gruesome acts. For example Al-Qaeda established its roots in countries like Somalia, Afghanistan, and Yemen etc. to get new recruits, physical space for training and regrouping. TTP did the same in FATA (Pakistan) and was successful in making ground because this part of Pakistan never enjoyed development and literacy rate was low too. Similarly, the situation in Iraq and Syria is no different, civil war in Syria and instability in Iraq without any central power to challenge, helped IS to fill the vacuum and establish their control on the weak areas. Hence, the international community must pay attention towards rehabilitation and development of these areas. So, the locals may enjoy a sense of ownership and no militant group would ever penetrate these societies. 


\subsection{Curbing Islamic State Financing}

Due to their immense financial assets, IS helping other terrorist organizations and establishing their branches in other countries. There is a dire need to curb their financing as soon as possible. A prominent development in this regard is the UN Security Council's resolution 1267, which has imposed sanctions on IS (Ryder, 2015). International community must also work together under the banner of UN and collectively snub the IS funding. The US and other regional countries have taken some action to disrupt illegal oil sales of the IS militants but the IS militants have got many other channels of funding which could only be disrupted when regional and global powers would make serious collaborative efforts.

\subsection{Enhanced Vigilance on Citizens Traveling to Syria and Iraq}

The IS militants use social media and highly advanced video for marketing campaign to promote their ideology and attract young recruits from around the globe (Stakelbeck, 2015). There are more than 300 Americans and hundreds of British young Muslims in IS ranks and now they are problematic to their own countries (Jay, 2014). This tendency must be disrupted, and vigilance should be increased on social media along with introduction of strict cyber laws to punish the offenders.

\subsection{Training of Syrian, Iraqi and Kurdish Forces}

The US withdrawal from Iraq left its security forces in limbo and not well trained. Perhaps, this was the major reason that IS militants overran Iraqi military bases in Mosul and other towns. Many countries are now training Iraqi and Kurdish forces at limited level. It is of vital importance that the US led coalition along with regional countries must help, train and equip the Iraqi and Peshmerga (Kurd) forces to effectively take on IS. On the Syrian side, countries like Russia, China and Iran can play a constructive role. The Syrian security forces and intelligence apparatus needs training on modern grounds to protect their country from terrorist factions in Syria. Pakistan could possibly play an effective and constructive role in this regard. Pakistan military is a professional force with extensive counter terrorism and counter insurgency experience. Pakistan can also extend support in training the Iraqi, Kurd and Syrian security forces on modern grounds.

\section{Conclusion}

The emergence of IS militants is not a problem of Iraq and Syria only. The nature and magnitude of this threat is beyond this region, thus, affecting global peace and security. The IS has no dearth of resources, funds or recruits presently. The IS has not only inspired likeminded people but also many militant groups in other countries have accepted Al-Baghdadi as their Caliph. The IS militants are enjoying physical space, while holding an area, establish control and then expand to other areas. 
The establishment of Caliphate by IS in Iraq is pathway to other areas in Middle East and South Asia to get more territory to consolidate its position worldwide to establish global Caliphate as dreamed by this group. It is noteworthy that the US led alliance would damage the operational capabilities of the IS in Iraq and Syria and as a result of that physical expansion may stop at a certain point. In addition to this, regional countries Iran, Saudi Arabia, and Turkey possess well trained and highly equipped militaries to stop the spread of IS in the region.

It is also assumed that South Asia might be the next station for IS, which should timely be dealt by the professional armies of Pakistan and India with the help of civil governments. It would be huge challenge for IS to fight against Pakistan and Indian armies, as both countries have extensive counter insurgency and counter terrorism experience. But the speculations can be made that South Asia may experience minute presence of IS in the areas politically and economically deprived. So, an early campaign launched in this regard would be quite fruitful.

We also reckon that a comprehensive strategy by the regional and global states should be formed with zero tolerance policy to counter this threat. We propose "3D Strategy" (Detection, Dispersion and Destruction) to combat IS with special focus on killing the leadership of this criminal organization. That strategy would also require a massive ground offensive to bring best results. The local community should be provided with sense of ownership and their rehabilitation should be promised after the success of this operation. Along with that de-radicalization program led by moderate religious scholars to counter extremist ideology of the IS may also be helpful. The development and reconstruction of the war ravaged areas must be a priority for the global community to bring structural peace in Iraq and Syria. After all, this becomes our collective responsibility on humanitarian grounds to help the native people of Iraq and Syria against the terrorists to make this world an abode of peace.

\section{References}

Ahmad, S. (Ed.). (2014). ISIS: The Rise of New Terror. New York: Book Around Publishing.

Ashraf, M. M. (2016, March 01). Getting rid of terrorism. The News International. Retrieved from http://www.thenews.com.pk/print/101945-Getting-rid-of-terrorism

The Asian Development Bank (2014, December 16). ADB to Boost Farm Productivity and Food Security in Pakistan Tribal Areas. Retrieved from http://www.adb.org/news/adb-boost-farm-productivity-and-foodsecurity-pakistan-tribal-areas

Allen, John R. (2014, December 30). The ISIL Threat: A Global Challenge. Retrieved from http://www.state.gov/s/seci/ 
Brisard, J. C., \& Martinez, D. (2014). Islamic State: the economy-based terrorist funding. Thomson Reuters, 3.

De Burca, A. (2014). Preventing political violence against civilians: nationalist militant conflict in Northern Ireland, Israel and Palestine: Springer.

Jeremy, B., \& Rosen, A. (2014, November 17). As ISIS Continues to Gain Ground, Here's What the Militants Have in Their Arsenal. INSIDER Retrieved from http://www.businessinsider.com/isis-militaryequipment-arsenal-2014-11?op $=1$

Bhatty, Z. A. (2014, February 19). The Pakistan Army's Operations in the Tribal Areas. from http://www.iiss.org/en/events/events/archive /2014-0f13/february-e91c/operations-in-the-tribal-areas-96f1

Cenciotti, D. (2015, October 08). Dramatic videos show Mi-24 Hind gunships fighting rebels in Syria. INSIDER Retrieved from https://theaviationist.com/2015/10/08/mi-24-against-rebels-in-syriavideos/

Dhiman, C. S. (2015). Islamic State of Iraq and Syria (ISIS) Reconciliation, Democracy and Terror. India: Neha Publishers \& Distributors.

Bryan, D. (2015, April 21). Inside the Coalition to Defeat ISIL. U.S. Department of Defense Retrieved from http://www.defense.gov/news/newsarticle.aspx?id=128630

Entous, A. (2016, April 12). U.S. Readies 'Plan B' to Arm Syria Rebels. The Wall Street Journal Retrieved from http://www.wsj.com/articles/u-sreadies-plan-b-to-arm-syria-rebels-1460509400

RANE (2016, March 18). Even As Russians Withdraw, Their Legacy in Syria Remains. Worldview Retrieved from https://www.stratfor.com/analysis/even-russians-withdraw-theirlegacy-syria-remains

Glint, M. (2014). Can a War with Isis Be Won?-ISIL/Islamic State/Daesh (Vol. 1). Conceptual Kings.

Hitchcock, M. (2016). ISIS, Iran, Israel: And the End of Days. Oregon: Harvest House Publishers.

Jenzen-Jones, N.R., \& Lyamin, Y. (2015, October 3). Russian forces deploy KAB-500S PGM in Syria. ARES Retrieved from http://armamentresearch.com/russian-forces-deploy-kab-500s-pgm-insyria/

Sekulow, J. (2015). Rise of ISIS: A threat we can't ignore. New York: Simon and Schuster.

Garamone, J. (2015, June 17). Success Against ISIL Requires Time, Partners, Dempsey Says". Retrieved from http://www.defense.gov/news/newsarticle.aspx?id=129064

Knight, C. J. (2015). Origin of Islamic state of Iraq and Syria. Happy life Guru Publishing. 
LaHaye, T., \& Hindson, E. (2015). Target Israel: Caught in the Crosshairs of the End Times. California, United States: Harvest House Publishers.

McInnis, K. J. (2016, April 13). Coalition Contributions to Countering the Islamic State. Congressional Research Service. Retrieved from https://www.fas.org/sgp/crs/natsec/R44135.pdf

Thompson, N., \& Shubert, A. (2015, January 14). The anatomy of ISIS: How the 'Islamic State' is run, from oil to beheadings. $C N N$. Retrieved from http://edition.cnn.com/2014/09/18/world/meast/isis-syria-iraqhierarchy/

Pleitgen, F., Hume, T., \& Yan, H. (2016, May 5). U.S. announces ceasefire for Aleppo after talks with Russia. CNN. Retrieved from http://edition.cnn.com/2016/05/04/middleeast/aleppo-syria-civil-war/

Ryder, N. (2015). The Financial War on Terrorism: A Review of CounterTerrorist Financing Strategies since 2001. New York: Routledge.

Rajab, F. (2014). The Positions of Germany in NATO towards the issues of The Arab World.Philip: Marburg University

Simha, R. K. (2015, March 11). How Russia's S-400 makes the F-35 obsolete. Retrieved from http://in.rbth.com/blogs/2015/03/11/how_russias_s400_makes_the_f-35_obsolete_41895

Silander, D., \& Don W. (2015). International Organizations and the Implementation of the Responsibility to Protect: The Humanitarian Crisis in Syria New York: Routledge.

Stakelbeck, E. (2015). ISIS Exposed: Beheadings, Slavery, and the Hellish Reality of Radical Islam. New York: Regnery Publishing.

Seán, N. D. (2015, June 9). Airstrikes Killing Thousands of Islamic State Fighters, but It Just Recruits More. Foreign Policy. Retrieved from http://foreignpolicy.com/2015/06/09/airstrikes-killing-thousands-ofislamic-state-fighters-but-it-just-recruits-more/

United Nations (2014, August 15). Security Council Adopts Resolution 2170 Condemning Gross, Widespread Abuse of Human Rights by Extremist Groups in Iraq, Syria. United Nations Security Council. Retrieved from http://www.un.org/press/en/2014/sc11520.doc.htm

Tucker, S. C. (Ed.). (2009). A Global Chronology of Conflict: From the Ancient World to the Modern Middle East [6 volumes]: From the Ancient World to the Modern Middle East. Santa Barbara, California: Abc-clio.

United Nations (2014, November 14). The Islamic State in Iraq and the Levant and the Al-Nusrah Front for the People of the Levant: report and recommendations submitted pursuant to resolution 2170. UN Security Council, Retrieved from http://www.securitycouncilreport.org/atf/cf/\%7B65BFCF9B-6D274E9C-8CD3-CF6E4FF96FF9\%7D/s_2014_815.pdf

US Department of Defense. (2016, May 22). Operation inherent resolve: targeted operations against ISIL terrorists. Retrieved from 
http://www.defense.gov/News/Special-Reports/0814_InherentResolve

Vatchagaev, M. (2016, March 3). Chechens Fighting in Syria Increasingly Joining Forces with Islamic State. Jamestown Foundation 13(43). Retrieved from http://www.jamestown.org/single/?tx_ttnews\%5Btt_news\%5D=45167 \&tx_ttnews\%5BbackPid\%5D=7\#.V0HTeDV97IU

N, S. (2015, September 30). Why Russia is an ally of Assad. The Economist. Retrieved from http://www.economist.com/blogs/economistexplains/2015/09/economist-explains-22

Yashar, A. (2015, November 26). Game changer? Russia says it deployed S400 in Syria. Israel National News. Retrieved from http://www.israelnationalnews.com/News/News.aspx/204019 